\title{
Is Microcredit a Viable Strategy for Empowering Women?
}

\author{
A Review of Selected NGO Programmes in Africa
}

\author{
Seidu Al-hassan \\ Centre for Continuing Education and Interdisciplinary Research \\ University for Development Studies, \\ Tamale, Ghana \\ Email: zodaseidu@yahoo.com \\ doi:10.4314/gjds.v8i1.5
}

\begin{abstract}
Microfinance institutions (MFIs) grant microcredits to hundreds of thousands of people, particularly women in developing countries with the aim of empowering them. The microcredits in the form of small loans to women are considered a tool for empowering women toward change in their socio-economic conditions. This paper investigates the impact of microcredit as a women's empowerment strategy. It draws from various impact assessment studies on microcredit programmes in Ghana, Cameroun and Gambia to examine issues on health and nutrition, education and skills development, income generation and, savings and investment as well as critique microcredit policies and strategies. It reveals that microcredit programmes are primarily reaching low income, moderately poor micro-entrepreneurs as target beneficiaries because majority of households have been able to acquire basic durable assets, such as bicycles, cooking pots, basins and roasters (cylinders). It concludes that microcredit programmes have positive impacts on women and the poor in spite of their challenges. It recommends, among others, that microfinance organizations revise their policies to address the challenges of women and target their socio-economic development needs and aspirations. Additionally, access to credit on sustainable basis is more important to the poor than receiving credit at subsidized interest rates.
\end{abstract}

Key Words: Microcredit, Women's empowerment, Micro-finance Policies, NonGovernmental Organizations 


\section{Introduction}

In recent years, microfinance has gained recognition as a strategy for reducing poverty among large and diverse groups of people. Microfinance is the provision of financial services (i.e., credit and savings) to a number of micro, small and medium entrepreneurs, the productive but resource poor especially women in a cost-effective and sustainable manner. It is an effort to counter the effects of credit market failures while empowering women beneficiaries socially and financially to access better health and educational facilities. The overall policy framework for microfinance in Ghana is informed by the poverty reduction strategy, which seeks to balance growth and macroeconomic stability with human development and empowerment with the view to reduce poverty levels in short and medium terms (Steel \& Andah, 2004).

There are two main kinds of microfinance institutions. The first are those who adopt the financial systems approach covering the provision of limited financial services for economically disadvantaged individuals who are employed or self-employed. The second are those who adopt the poverty lending approach. The poverty lending approach involves subsidized financial services (often accompanied by training or other assistance) for economically disadvantaged and marginalised individuals (Kabeer, 2005). In Ghana, poverty lending approaches are particularly concerned with offering easy and inexpensive alternatives to high-interest informal moneylenders and to provide accessible credit to the poor to be used in entrepreneurial ventures that contribute to sustainable livelihoods and reduce poverty. The microcredit and microcredit information are usually provided through a number of different sources: the public sector (e.g., the Microfinance and Small Loan Center (MASLOC)), independent non-profit organizations, community-based organizations (CBOs) and commercial financial institutions (Rural Banks) and other institutions (GHAMFIN) ${ }^{31}$. Egyir and Akudugu (2009) reported that the most successful microcredit institution in Ghana, with the largest number of clients $(16,000)$ is Sinapi Aba Trust (STA). Other well-known ones include Women's World Banking, ProCredit Ltd., Opportunity International, Ezi Savings and Loans, Eclof Ghana, UniCredit, and Express Savings and Loans. NGOs such as Simli Pong, Grammeen Ghana, Simli Aid and Community Life Improvement Programme (CLIP) have also been involved in microfinance. Microcredit providers serve a particular geographic area or community, or a particular group of people. The loans vary from one community to the other or one geographical area to the other. Most of these loans come with technical support such as business training, mentoring, peer exchanges and/or networking opportunities.

According to Todaro and Smith (2004) development must be conceived of as a multidimensional process involving major changes in social structures, popular attitudes

31 In 1998, the Ghana Microfinance Institutions Network (GHAMFIN) was established as an umbrella organization with over 70 regulated and non-regulated Microcredit institutions. The objective of GHAMFIN is to serve as a knowledge-center for the microfinance industry and to provide information and statistics. GHAMFIN is also providing staff training and assistance with capacitybuilding. 
and national institutions, as well as the acceleration of economic growth, the reduction in of inequality, and the eradication of poverty. Moser and Dani (2008) report that evaluating the performance of microfinance institutions in terms of their sustainability and, in some cases, profitability is reasonably straightforward, but evaluating their impact on poverty reduction, development, and entrepreneurship is more complicated. Although a number of studies including Egyir and Akudugu (2009), Egyir (2008), Seidu and Bambangi (2006), Kabeer (2005) and Republic of Ghana (1999) have shown that microfinance is key to promoting socio-economic development through poverty reduction, other works such as Chowdhury (2008a) and Chowdhury (2008b) have found that microcredit have failed to promote entrepreneurial or business growth, particularly for women. The critical question that needs to be answered is: To what extent is microfinance useful as a strategy for improving socio-economic development and especially for women's empowerment?

This paper examines the role of microcredit in promoting the socio-economic development of women in society. This is done through the identification and analysis of microfinance strategies, lessons learned from implementing microfinance programmes and the challenges facing microfinance institutions and beneficiaries. The paper reviews reports of six end-of-project evaluations on selected NGOs, namely Youth and Women Empowerment (YOWE) of Ghana, Simli Pong and Simli Aid of Ghana, Mbororo Social and Cultural Development Association (MBOSCUDA) of Cameroun, Village Aid Gambia and Village Aid UK to examine the importance of microfinance in women's socio-economic development ${ }^{32}$.

Women's empowerment is defined to mean improving women's income, health and nutrition, education and employment status of women as well as savings and investments and the ability to participate in decision making processes at household and community levels. The rest of the paper is organized as follows: Section one deals with the performance of microcredit in empowering women through promoting socio-economic development in society. Strategies used for implementing microfinance programmes are presented in Section two whereas Section three examines challenges facing microfinance institutions and target beneficiaries. Key lessons derived from implementing microfinance programmes are presented in Section four. The last section comprises conclusions and recommendations.

\section{Microfinance And Women's Empowerment}

Yunus (1975) has stated that one single action which will enable the poor and the vulnerable to overcome their poverty is credit. The explanation is that in numerous instances, microcredit has helped alter perceptions regarding women's contribution to economic and social development and their role in this regard. More specifically, microcredit has led to greater recognition of women's capacity to commit to work that

32 Mbororo Social and Cultural Development Association is based Cameroon and YOWE is Youth and Women Empowerment based in Somanya, Koforidua, Ghana.

74 GJDS, Vol. 8, No. 1, May 2011 
produces income. Loans to women have a greater knock-on effect, children benefit from the increase in a mother's income. Women who borrow money establish links of solidarity through their involvement in lending circles and in village organisations. Studies by Berger (1995), Coleman (1999), Khanderker (1998), Khandker (2005), Osmani (1998) and Osmani (2005) have shown that greater financial autonomy may have wider social implications, notably in terms of a greater say for women in family matters, including the family finances. Thus, in the context of wider efforts to raise women's consciousness and to mobilise them, credit may have an important contribution to make as a first step towards empowerment. By participating in microfinance programmes, women widen their contacts initially and consolidate their links with other women via meetings. Next, their ability to command and repay loans and accumulate savings is likely to boost their confidence and self-esteem (Sinha, 1998).

Specifically, credit programmes empower women by strengthening their socio-economic roles, increasing their ability to contribute to the family's income, helping them establish their identity outside of the family, and giving them experience and confidence in the public sphere (Sinha, 1998). In Ghana, the increase in confidence level of women has made it possible for them to occupy positions in REFLECT circle committees (Simli Aid, 2005), Unit Committees and other community- based organizations. Seidu and Bambangi (2006) showed that women's access to financial services has enhanced their decision-making capacity in the Kassena-Nankana District in the Upper East Region of Ghana. When women participate in a credit scheme, they are encouraged to make certain decisions, relating among others, to their income-generating activities. Seidu and Bambangi (2006) have concluded that women in the Kassena-Nankana District who had access to microcredit became more aware of their abilities and took legitimate pride in their achievements.

\section{Incomes and Poverty Reduction}

The Republic of Ghana (1999) provides evidence to show that the poor can become productive and subsequently increase their savings when given access to sustainable financial services. The study found that by providing microcredit to its clientele, Sinapi Aba Trust (SAT) increased the household incomes of its clientele on the average by $157 \%$ for the period August 1994 and July 1997. Further, 33\% of sampled enterprises engaged new hands whereas employment in general increased by $46 \%$. YOWE (2005) reports that $35 \%$ of microcredit women beneficiaries experienced improvement in their income levels and were able to expand their businesses, cater for their children's education and their families' health needs. This indicates that the economic empowerment of women through loans (microcredit) contributes immensely to the alleviation of household poverty. Simli Pong (2008) also shows that about $45 \%$ of beneficiaries increased incomes and thus earned a higher level of respect in their societies, especially from their husbands. The improvement in clients' income manifests itself in several ways including clients' ability to expand their existing enterprises, increase frequency of visits to markets, improve production methods, increase knowledge about the market and buy raw materials 
(inputs) on cash. Clients' average annual income also witnessed a steady and faster growth rate compared to non-clients (See Figure 1 below) indicating that microcredit is an important strategy for poverty alleviation (Seidu and Bambangi, 2006) ${ }^{33}$.

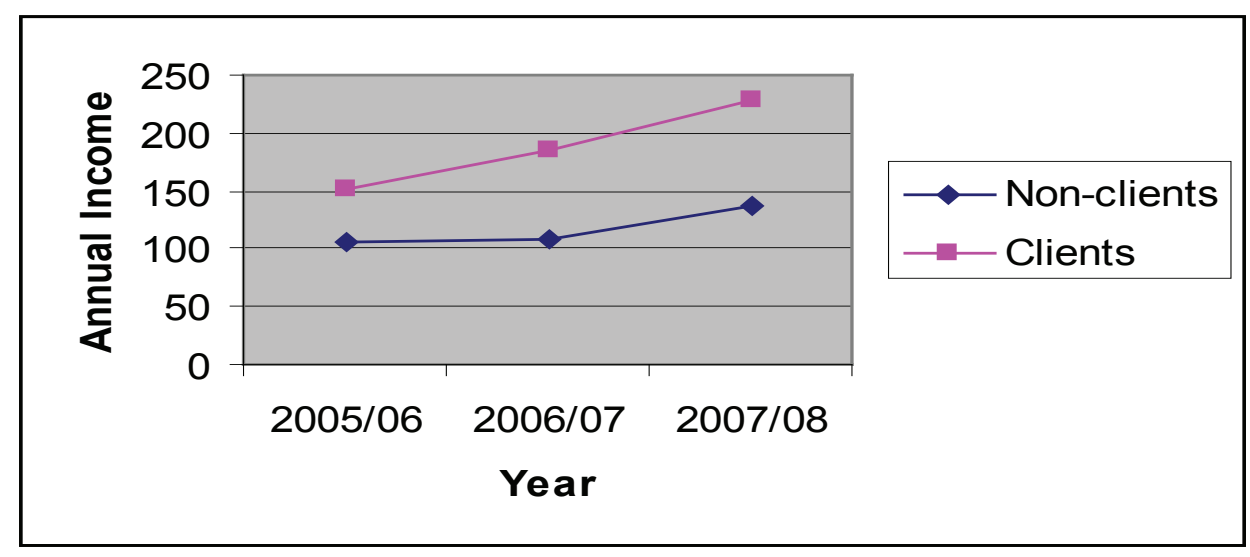

Figure 1: Growth in average annual income of clients and non-clients.

Source: Simli Pong, 2008.

In 2006, Village Aid UK provided evidence to show that microfinance is useful for improving the lives and businesses of the poor and vulnerable women who are economically disadvantaged. Table 1 summarizes the information regarding the impact of microfinance on women, men, youth and the disabled.

Table 1: Most significant changes identified by beneficiaries

\begin{tabular}{|c|c|}
\hline Peer group & Most significant changes identified by beneficiaries \\
\hline Men & $\begin{array}{l}\text { - Increased income for women } \\
\text { - Increased household food supply } \\
\text { - Increased savings }\end{array}$ \\
\hline Women & $\begin{array}{l}\text { - Improved status of women (empowerment) } \\
\text { - Reduced dependency on men by women and girls } \\
\text { - Increased rural entrepreneurship } \\
\text { - } \text { Reduced unemployment } \\
\text { - Increased growth in small business enterprises } \\
\text { - Increased savings }\end{array}$ \\
\hline
\end{tabular}

33 Karlan and Zinman (2009) are of the view that increased access to credit increases profits (income) for male but not for female micro-entrepreneurs. 


\begin{tabular}{|l|l|}
\hline & - Increased rural entrepreneurship \\
\hline Youth & • Reduced unemployment \\
\hline & Increased growth in small business enterprises \\
\hline \multirow{3}{*}{ Disable } & - Increased rural entrepreneurship \\
& - Increased growth in small business enterprises \\
\hline
\end{tabular}

Source: Village Aid UK, 2006.

\section{Gender Relations in the Household}

Sinha (1998) reports that by developing her microenterprise a woman is able to contribute to the family's income and thus acquires a certain measure of autonomy. Access to credit thus seems to have implications for gender relations within the home. Sinha (1998) argues that change on this front may be slow, but it represents a step towards greater equality between men and women. Microcredit may have a favorable impact on domestic violence as well as providing women with a means of escaping from an abusive relationship. This is because more than $60 \%$ of women who participated in its microcredit scheme have been empowered to take active part in decision making process at the household level (Simli Pong, 2008). The awareness of loan beneficiaries about participatory approach to managing households also increases leading to enhanced peace (i.e., less quarrels) at homes. The women appear more confident and enlightened, know their fundamental human rights and as such take active roles in decisions requiring expenditure. The Simli Pong Credit Programme in Ghana has succeeded in breaking the age long barrier that women have no role in managing households whereas MBOSCUDA in Cameroon succeeded in breaking the culture of silence (Pulaaku) among women through microcredit.

\section{Health and Nutrition}

Village Aid, UK (2006) reported that the nutritional status of men and women who received microcredit improved because many of them used the loans to farm soya beans for domestic consumption ${ }^{34}$. According to Simli Pong (2008) 95\% of women who participated in the microcredit scheme were able to meet their health needs and the health needs of their family members. On the ability to practice family planning, 33\% said they practice family planning and as high as 53\% of the beneficiaries were able to register for National Health Insurance Scheme (NHIS) based on returns from their entities. Ninety five percent (95\%) of clients said they improved their household nutrition status (Simli Pong, 2008). For instance, a beneficiary narrated her ability to pay GH $\$ 150$ as medical expenses to cure herself based on the gains she derived from her business. Further, loan beneficiaries were able to increase their nutrition status by $50 \%$. They experienced

34 Soya bean is an important source of protein. 
improved nutrition which was measured by beneficiaries' ability to consume food items like tomatoes, onions, fish (yura yura) and magi. Majority of loan beneficiaries said they could meet about $70 \%$ of their food requirements as compared to $40 \%$ before the project (Table 2).

Table 2: Health Effect of Loan for Clients and Non-clients

\begin{tabular}{|c|c|c|c|c|c|c|c|c|}
\hline \multirow{3}{*}{ Description } & \multicolumn{4}{|c|}{ Clients } & \multicolumn{4}{|c|}{ Non-clients } \\
\hline & \multicolumn{2}{|l|}{ Yes } & \multicolumn{2}{|l|}{ No } & \multicolumn{2}{|l|}{ Yes } & \multicolumn{2}{|l|}{ No } \\
\hline & Freq & $\%$ & Freq & $\%$ & Freq & $\%$ & Freq & $\%$ \\
\hline Able to effect own health & 349 & 95.4 & 14 & 3.8 & 112 & 91.8 & 10 & 8.2 \\
\hline Able to effect family & & & & & & & & \\
\hline members' health & 343 & 93.7 & 23 & 6.3 & 111 & 91.0 & 11 & 9.0 \\
\hline relations' health & 280 & 76.5 & 86 & 23.5 & 66 & 54.1 & 56 & 45.9 \\
\hline Able to purchase medicine & & & & & & & & \\
\hline $\begin{array}{l}\text { when needed } \\
\text { Attend hospital/clinic in }\end{array}$ & 344 & 94.0 & 22 & 6.0 & 114 & 93.4 & 8 & 6.6 \\
\hline times of sickness & 322 & 88.0 & 44 & 12.0 & 104 & 85.2 & 18 & 14.8 \\
\hline Able to practice family & & & & & & & & \\
\hline planning of choice & 115 & 31.4 & 251 & 68.6 & 15 & 12.3 & 107 & 87.7 \\
\hline Able to register for NHIS & 193 & 52.7 & 173 & $47 \cdot 3$ & 29 & 23.8 & 93 & 76.2 \\
\hline Able to improve nutrition & 346 & 94.5 & 20 & $5 \cdot 5$ & 80 & 65.6 & 42 & 34.4 \\
\hline
\end{tabular}

Source: Simli Pong, 2008.

\section{Children's Education}

Girl-children are most affected and marginalized within the current social context due to the low status of women and socio-cultural conditions, which restrict their participation in formal and non-formal education. Traditional and social customs such as early marriage, child fostering and the preference for boys' education continue to restrict many girls from enrolment, retention and transition through the education system particularly in the northern regions of the country. The analysis shows that an improvement in women's income manifests itself in several forms including the ability to pay children's school fees, to foot self and other relatives' medical bills and to contribute to household food needs. Simli Pong (2008) and Egyir (2007) have indicated that women who participate in microcredit programmes have been able to pay the school fees of their children, buy school uniform and other teaching and learning materials (TLMs), attend parent teacher association (PTA) and school management committee (SMC) meetings ( Table 3). 
Table 3: Education Effect of Loan on Clients and Non-clients.

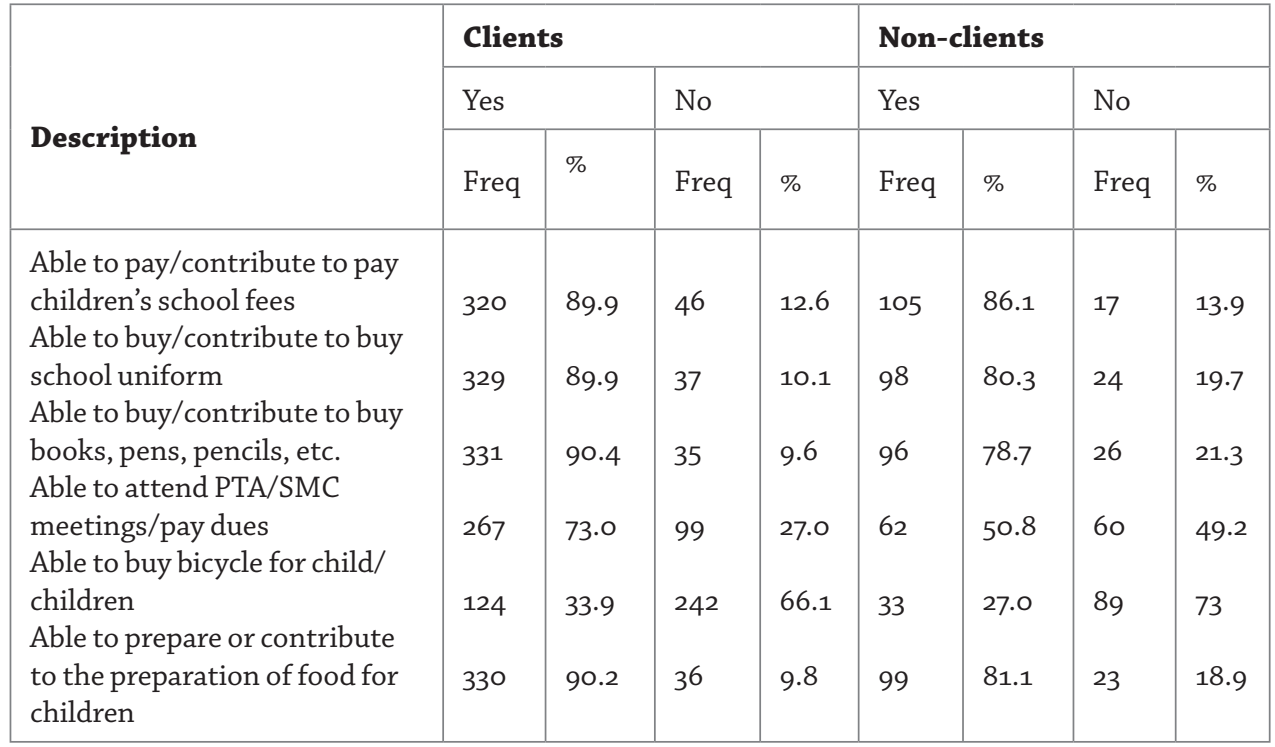

Source: Simli Pong, 2008.

\section{Savings and Investment}

Sinha and Matin (1998) and Asenso-Okyere, Asante and Gyekye (1993) found that small loans are usually used for investment and retail or for acquiring new skills such as fish farming, brick making, butchery, production of art and crafts, crop farming, weaving and pottery. Such diversification ensures that there is no over-concentration on any given activity, which may adversely affect loan repayment due to the economics of competition. Simli Pong (2008) proofed that loan beneficiaries' did weekly mandatory group savings a day after each market day. Mandatory savings are important because they help women to mobilize domestic resources for onward investment. Women beneficiaries (36\%) make weekly contributions of between five and twenty Ghana cedis. Simli Pong (2008) indicated that the mean savings for clients was almost double ( $\mathrm{GhC}_{1.9}$ ) that of non-clients ( $\mathrm{GhC}_{1}$ ). In addition, 30\% of clients operated group accounts with Agricultural Development Bank (ADB) and Borimanga Rural Bank whereas there was no evidence about non-clients ability to operate group accounts. Another thirty percent (30\%) sponsored the provision of shelter or stall for their enterprises whereas over 9o\% of the clients acquired assets like bowls, basins (taha) and pots (dugri) to promote their businesses. Basins and pots constitute important fixed assets for micro-entrepreneurs in the study area. However, savings in social capital measured in terms of beneficiaries' ability to lend moneys to others was found to be weak among both clients and non-clients largely due to mistrust. The simple reason is that such act is characterized by a high rate of disappointments (i.e., high default rate). Forty percent (40\%) of loan beneficiaries of YOWE's microcredit 
scheme made savings, increased investments (i.e., building of houses, paying school fees, ploughing back profits into the business and buying food stuffs to store) and handled other expenditures (i.e., water and electricity bills, funeral and child naming expenses and loan servicing.

\section{Growth of Businesses and Skill Development}

Expansion in the number and the types of products sold by women beneficiaries is another impact area of microcredit. On average enterprises owned by women loan beneficiaries grew by more than 50\% (Simli Aid, 2005). The types of products that the women use their loans to expand include shea butter, groundnut oil, cassava, flour, maize flour, kulikuli, dawadawa, soup ingredients, sale of clothes, cereals and household utensils. Others took the loan to expand their vegetable farms, firewood and charcoal business and to cook and sell food (i.e., TZ, adua, etc) and buy and retail foodstuff. A beneficiary in Tamale narrates her success story as follows:

"I have taken the loan for about two times. I deal in scrap business (buying and selling). I am the magazia of the Wumpini women's group. I buy the scrap in Tamale and sell them at Burkina Faso. I in turn buy beans and groundnuts from Burkina Faso and sell in Tamale. I have been able to make good profit and this has contributed to my ability to acquire two taxis".

Small loan beneficiaries in Zazi community said they utilized the loan to expand their vegetable farms. Vegetable farms increased in size by $30 \%$. Nevertheless, there was no evidence of any significant diversification in terms of adding new products into the market. The production of traditional products (shea butter, rice parboiling, farming, etc) still dominates. This is unfortunate in that it does not help business diversification in the short run or survival in the long run. Similar conclusion has been reached by Chowdhury (2008a) that the participation in the microcredit programmes does not promote women entrepreneurship at the household level ${ }^{35}$.

The experience of Village Aid UK indicates that microcredit has had a tremendous impact on the lives of the people of Northern Region of Ghana. The explanation is that beneficiaries of the credit were able to expand their farms, employ labor, increase food production and savings. Agricultural output, particularly food crops, increased by almost three fold due to the synergy effect of the REFLECT, compost and credit support schemes. Increased output brought about improvement in the incomes of the people. There was also an increased involvement in agricultural activities such as semi-improved sheep

35 Chodhury assessed the impact of the participation in microcredit programmes in Bangladesh on women entrepreneurship development at the household level. The main objective was to determine whether the participation in the microcredit programmes helped participating women to start their own businesses and to create employment for other people. The analysis was based on a householdlevel survey of 920 households drawn from top three micro finance institutions. 
production, gardening (i.e., pepper, huckleberry and cabbage cultivation), as well as processing and commercialization of farm produce like maize and rice.

Women loan beneficiaries have gained increased knowledge about business issues through participating in the capacity building workshops or meetings organized by microfinance institutions. Over $68 \%$ of beneficiaries have been equipped with knowledge on important business promotion areas such as business management, savings, health and sanitation, income, revenue, seasonality of products, sources of raw materials, transportation, storage, market and price determination. Generally, beneficiaries' knowledge about the link between the quality of a product and its market has been deepened equipping them with skills of increasing market share through quality produce. Simli Pong (2008) indicated that loan beneficiaries learned skills and experiences more than the non-clients (Table 4). Ninety nine percent (99\%) of the clients explained that they had increased their solidarity for other group members whereas $75 \%$ of non-clients felt same towards their groups (Table 4). In terms of confidence and self-esteem, 91\% of the clients gained these aptitudes compared to non-clients (81\%). Another $95 \%$ of clients indicated that participating in the loan programme had enhanced their business management ability. As such, more clients (94\%) experienced growth in their business compared with non-clients (62\%) (See Table 4). More so, $80 \%$ of women beneficiaries had gained experience and skills in leadership. The women explained that participating in group activities offered them a great opportunity to come together to talk about various socioeconomic issues, such as health care, nutrition, and business decisionmaking practices. Thus, clients described the skills training of loan schemes as positive because the realities of confidence, self-esteem and group solidarity are impacts the women considered very crucial. Box 1 presents the role of microfinance in socio-economic development using the experience of MBOSCUDA.

Table 4: General/leadership Skills and Experience.

\begin{tabular}{|c|c|c|c|c|c|c|c|c|}
\hline \multirow{3}{*}{ Description } & \multicolumn{4}{|c|}{ Clients } & \multicolumn{4}{|c|}{ Non-clients } \\
\hline & \multicolumn{2}{|l|}{ Yes } & \multicolumn{2}{|l|}{ No } & \multicolumn{2}{|l|}{ Yes } & \multicolumn{2}{|l|}{ No } \\
\hline & Freq & $\%$ & Freq & $\%$ & Freq & $\%$ & Freq & $\%$ \\
\hline Learnt saving skills & 312 & 85.2 & 54 & 14.8 & 76 & 62.3 & 46 & 37.7 \\
\hline Able to meet basic family needs & 353 & 94.6 & 13 & 3.6 & 108 & 88.5 & 14 & 11.5 \\
\hline $\begin{array}{l}\text { Increased solidarity for other } \\
\text { members of group/community }\end{array}$ & 361 & 98.6 & 5 & 1.4 & 91 & 74.6 & & 25.4 \\
\hline Gained confidence \& self esteem & 332 & 90.7 & 34 & 9.4 & 99 & 81.1 & 23 & $\begin{array}{l}23.4 \\
18.9\end{array}$ \\
\hline Able to use money more & & & & & & & & \\
\hline optimally & 348 & 95.1 & 18 & 4.9 & 98 & 80.3 & 24 & $19 \cdot 7$ \\
\hline Business has grown & 344 & 94.0 & 22 & 6.0 & 76 & 62.3 & 46 & 37.7 \\
\hline
\end{tabular}

Source: Simli Pong, 2008. 


\section{Box 1: Achievements of Mbororo Social and Cultural Development Association in Cameroon}

MBOSCUDA's micro-credit scheme started in 2000 and is based on altruism or the welfarist approach of micro-finance. It is conventionally referred to as the Credit-First approach however, with a strong focus on adult literacy using the REFLECT and PRA approaches. The programme is designed towards bridging the gender gap in Mbororo communities especially in the domain of decision making and social empowerment aimed at challenging perceptions vis$\grave{a}$-vis the status of Mbororo women. The scheme is not business oriented but geared towards attaining a high social objective.

The microfinance of MBOSCUDA has made number successes in the Mbororo community in Cameroon. There has been a registration and official recognition of groups as Common Initiative Groups (CIGs). $16.1 \%$ of groups are always invited to public meetings in their localities leading to increased group participation in other development programs in the community. The microfinance programme brought about increased use of formal financial institutions (Local Credit Unions). 100\% of groups save with local credit unions and 3\% of women in groups have individual accounts. There has been increased social integration and co-existence between Mbororo communities and their farming neighbors through buying and selling of items and use of community resources and reduced negative culture such as "pulaaku" (culture of silence) and increased self - esteem of women. Specifically, Mbororo women have developed the courage to approach men to claim debts, share ideas and contribute in decision making. There has also been increased advocacy and realization of girl child education which is also supported financially by women. The programme also led to an increase in income for women groups. The average profit per group is 144,558 FRS (29\%). More so, some groups were able to generate income of more than $40 \%$. Through group activities, women are contributing enormously in developing the rural economy. There is availability of day-to-day needs at community level which has reduced the usually distance covered by community members to get to the market. Finally, the members of the Mbororo community witnessed an increase in unity amongst members due to joint business and common interest.

Source: MBOSCUDA, 2008.

\section{Microcredit Policies and Strategies}

Egyir (2008) reports that the primary elements of micro loan supply includes requirements for loan application, loan ceiling amounts, interest rates, repayment schedules and processing period whereas the secondary elements include human resource, infrastructure, research and external support. Generally, loan applicants for micro loans need to provide adequate identification and show their credit worthiness, agree to weeks of processing period, average monthly interest rates of 3 percent and monthly repayments schedule. Microcredit policies have been formulated in order to 
guide the effective and efficient delivery of credit to the poor. Such policies clearly indicate the target beneficiaries (i.e., who qualifies for the loan); loan size, cycle and duration; loan price (interest rate) and how to handle loan default or delinquency ${ }^{36}$. Rural women micro entrepreneurs are not a homogeneous group because they vary by age, literacy, ethnicity and economic activities engaged in (Egyir, 2008). Suppliers of the credit (firms), first of all, profile the target beneficiaries before any intervention. Micro loans providers need to understand the characteristics of clients, have adequate logistics, undertake regular enquiry/research and relate with other agencies that can support their social welfare budget (Egyir, 2008). This is usually done through community situational analysis involving community visits, community meetings, baseline studies and community needs assessments. Knowing the target beneficiaries is paramount for the determination of the capabilities and potential of beneficiaries so as to fix loan amounts, loan cycle, loan duration and the interest rate. The situational analysis also enables MFIs to realize the type of microenterprises that need support. Indeed, because most of the microcredit programmes are characterized by demand-driven approach, the policy of knowing the beneficiaries enables them to identify interest groups or individuals.

In Ghana many microcredit schemes target women. The reason is that women are more vulnerable and as such there is the need to empower them through the provision of credit. As indicated earlier in the paper women use the credit to expand their small businesses and to enhance their status in the communities. This policy is restrictive in nature because microfinance institutions usually focus on a particular group of people. This policy is perhaps influenced by the fact that microfinance institutions lack adequate funds to meet the increasing demand for credit. The policy of limiting credit to only a particular group of people is criticized on the grounds that it can drive away potential rural microentrepreneurs who have the potential to become successful businessmen.

Interest rate is the price of credit and is often used as loan price. The interest rate ranges between 10 and $30 \%$. Microcredit organizations charge interest to make profit in order to defray part of the cost of providing and maintaining credit. The institution of interest rate is interpreted by most MFIs as necessary for programme sustainability. Nevertheless, most MFIs unilaterally decide the rates and slap them on loan beneficiaries. Other factors that contribute to the determination of interest rates are inflation and cost of fuel. The implication is that changes in inflationary rate and fuel prices negatively affect enterprise development in rural areas through the loans that they receive.

Group-based and individual-based credits are the two main lending approaches. Unlike individual-based credit approach the group-based credit approach is favored by many MFIs because it is packaged with responsibilities (meeting attendance, forced saving and shared default risk). On the other hand, decision making under individual loan scheme is fast making it more attractive. Nevertheless, neither group-based nor individual based learning is a means to an end. The most important thing is to effectively monitor the

36 All organizations have loan ceiling as a result of limited funds. The cycle of credit is the number of times a beneficiary can take loan within a particular period of time. 


\section{S. Al-hassan: Is Microcredit a Viable Strategy}

activities of loan beneficiaries and staff directly involved in handling credit (e. g., credit/ loan officers).

Current trends show that MFIs run credit with education (literacy and skills training) perhaps because of the belief that skills training improve the entrepreneurial abilities of loan beneficiaries. The belief is that literacy plus credit is equal to empowerment (Simli Aid, 2005). Credit with education is intended to assist loan beneficiaries in the efficient utilization of the credit. This is understandable because lack of literacy prevents people from being able to function more effectively in the larger socioeconomic and political environment through improved communication and social interaction (Owusu-Mensah, 2007). Beneficiaries are trained in areas such as business planning and management, record keeping, profit and loss computation, fund raising, leadership, group dynamics and conflict resolution. Credit with education strategy is essential because it will go a long way to empower the most marginalized who are not only vulnerable but also lack resources to help themselves or are unable to claim their rights. For example, the Freedom from Hunger's Credit with Education programme uses individual savings with group credit to target women and provide accompanying education on health, nutrition, family planning, financial planning and budgeting and microenterprise development.

The strategy for credit delivery differs from microcredit to microcredit. An important policy of credit schemes is the establishment of loan beneficiary selection criteria. These criteria are designed to select target beneficiaries from the communities in order to ensure that the motive for granting support to poor people is not defeated. The implication is that MFIs try to avoid ill targeting, which is a common pitfall for most microfinance institutions. Credit is disbursed by staff of MFIs mostly in the communities, that is, direct to beneficiaries. The experience of MBOSCUDA in Cameroon indicates that Credit Unions are used for loan disbursement and repayment. Microcredit organizations have instituted a number of mechanisms to ensure prompt and regular recovery in order to minimize loan defaults or delinquency.

MFIs also ensure that credit provided to individuals and/or groups of individuals are constantly monitored. The explanation is that monitoring provides them the chance to know how small loans are employed by different categories of beneficiaries and whether or not the loan facility is yielding any impact. Monitoring also enables staff of beneficiary organizations to improve their loan policies or strategies based on lessons learnt. The argument is that monitoring increases accountability on the part of staff. It is against this background that MFIs have appointed credit officers to be solely responsible for credit management. Credit officers report all matters concerning credit to project management. Microcredit organizations said that they specifically monitor loan repayments, savings passbooks, progress of business activities, use of credit, impact of credit and individual and group problems. 


\section{Challenges of Microfinance}

MFIs face a number of challenges including:

- High cost of running the program that threatens its sustainability.

- Challenging settlement characterized by bad roads, distant and enclave settlement. The large and dispersed coverage affects effectiveness.

- Concealing of monetary information by potential and actual beneficiaries leading to difficulty in credit planning and monitoring.

- Inability of MFIs to meet ever increasing demand for loans.

- Problems (internal conflicts) associated with group-based lending that threatens programme sustainability.

- Microcredit operation requires a lot of record keeping hence inadequate office equipment like safe, cabinet and computers affect the smooth operation of the system.

- Embezzlement of money by staff

Loan beneficiaries also face the following challenges:

- High loan price (interest) which affects profit and business growth as well as repayment.

- Over $60 \%$ of microcredit goes into promoting enterprises in agriculture and as such. Poor weather conditions (e.g., poor rainfall pattern) or animal disease can lead to crop failure or death of animals thereby weakening beneficiaries' loan repayment ability.

- Men seizing their spouses' moneys (diversion of credit). For example, the Bangladesh Women's Entrepreneurship Development Programme indicated that many husbands forced their wives to take loans that were actually used to finance the husband's activities; the women were then left with debts and no means to pay it.

- Poor training for beneficiaries. Despite the immense advantages of the training workshops that serve as important source of business knowledge, the sampled clients complained that only a few of them (about 17\%) receive the trainings. Those who are usually trained constitute the executive members. The expectation is that trained executive members will in turn train other members. This does not usually happen because of high rate of illiteracy. Group members' knowledge about business issues is also limited by poor record keeping.

- Perception of a section of the general public that women only need small or little amount of capital to start or operate their businesses as compared to their male 


\section{S. Al-hassan: Is Microcredit a Viable Strategy}

counterparts. The thinking is that women are relatively better in managing small amount of productive resources.

- Caring for young children precludes women from developing their microenterprises. Moser and Dana (2008) reported based on the experiences of South Africa and The Arab republic of Egypt that the women who developed their microenterprises into successful and sustainable businesses that enabled them to accumulate assets tended to be single, lived at the margins of their communities and had children older than 10 years. Moreover, they were linked to support systems such as NGO networks outside their community.

- Difficulty for women microenterprise owners to see themselves as businesswomen, because of community pressure to conform to the local cultural ideal of 'a good woman'.

\section{Conclusion}

From the above it can be concluded that microcredit programmes have had positive effects on women and the poor in spite of their challenges. Beneficiary women have been able to improve their socio-economic conditions through investments in personal assets, business development, productivity and skills development. Such improvements have enabled the women to build social networks, improve their image, invest in family welfare, reduce vulnerabilities and expand their choices. To that extent micro-credit can be considered a viable strategy for empowering women. However, the challenges outlines above need to be addressed in order to enhance their effects in positively transforming the lives of beneficiary women.

\section{Recommendations}

Berger (1995) argues that the demand for credit by small borrowers tends to be relatively interest-inelastic. As such, access to credit on sustainable basis is more important to the poor than receiving credit at subsidized interest rates (Republic of Ghana, 1999). It is therefore important for microcredit organizations to set interest rates to cover the inter-mediation costs so that the financial intermediary is financially viable and can provide credit over the long term. This is far more important to rural entrepreneurs than subsidized credit programmes which may not be sustainable.

Over $60 \%$ of microcredit is provided to beneficiaries engaged in agro-processing activities. This is as a result of agriculture being the dominant sector of many countries implementing microcredit programmes. However, weather problems like poor rainfall and animal disease do not only retard enterprise development but also they negatively affect loan beneficiaries' ability to repay. It is recommended that future credit support should diversify into supporting rural enterprises in industry. Microfinance institutions should include in the design of credit programmes sustainable environmental development. 
Emphasis should be placed on economic use of natural resources, water and soil management, waste management, etc. Future programmes that aim at poverty reduction especially at the household level should target men. The argument is that programmes that target exclusively women can have unintended results that leave some worse off (Berger, 1995).

More so, women's business practice should change from thinking subsistence to thinking entrepreneurship. It is only then that record keeping and information seeking for innovativeness will be pursued. Owners of firms under local industries need to be oriented to cultivate a profit maximization behavior or attitude. This is because financial performance is the single most dramatic measure of organizational health and business success. The most direct indicator of financial performance is captured in the concept of profit or firm value. Owners of firms under local industries need to aim at meeting customer needs and values.

\section{References}

Asenso-Okyere, W. K, Asante, F. A and Gyekye, L. O. (1993). Policies and Strategies for Rural Poverty Alleviation in Ghana, ISSER, University of Ghana, Legon.

Berger, M. (1995). "Key Issues on Women's Access to and Use of Credit in the Micro- and Small-Scale Enterprise Sector" in Digard, L and Havet, J (ed.), Women in Micro-and SmallScale Enterprise Development, Westview Press, Boulder, pp. 190-215.

Chowdhury, M. J A. (2008a). "Does the participation in the microcredit Programmes Contribute to the Development of Women Entrepreneurship at the Household Level?

Experience form Bangladesh", CDM Working Paper 04, Center for Microfinance Development, University of Dhaka, Bangladesh, pp. 1-21.

Chowdhury, M. J A. (2008b). "Microfinance and Environment: Does the participation in the Microcredit Based Social Forestry of Proshika in Bangladesh Improve Environmental Literacy?" CDM Working Paper 05, Center for Microfinance Development, University of Dhaka, Bangladesh, pp. 1-24.

Coleman, B. E. (1999). “The Impact of Group Lending in Northeast Thailand”, Journal of Economics, Vol. 6o, pp. 105-141.

Egyir, I and Akudugu, M. A. (2009). "Rural Women and Microfinance in Ghana: Challenges and Prospects", Unpublished, pp. 1-16.

Egyir, I. (2008). "Improving Microfinance Services for the Rural Woman in Ghana", Draft Report Submitted to the Christian Mothers' Association, Accra. 


\section{S. Al-hassan: Is Microcredit a Viable Strategy}

Kabeer, N. (2005). “Is Microfinance a 'Magic Bullet' for Women's Empowerment? Analysis of findings from South Asia”, Economic and Political Weekly, October 29: 4709-18.

Karlan, D and Zinman, J. (2009). "Expanding Microenterprise Credit Access: Using Randomized Supply Decisions to Estimate the Impacts in Manila”, Center Discussion paper No. 976, Economic Growth center, Yale University, New Haven, pp. 1-20.

Khandker, Shahidur R. (2005). Microfinance and Poverty: Evidence Using Panel Data from Bangladesh. World Bank Economic Review 19(20): 263-86.

Khandker, S. R. (1998). "Micro-credit programme Evaluation: A critical Review" in Sinha, S (ed) Micro credit: Impact, Targeting and sustainability, IDS Bulletin, Vol. 24, No. 9.

Moser, C and Dani, A. (2008). Assets, Livelihoods, and Social Policy. The World Bank, Washington, D.C.

Owusu-Mensah, F. (2007). "Ghana non-formal education: country profile prepared for the Education for all, Global monitoring report 2008, education for all by 2015: will we make it?" 2008/ed/efa/mrt/pi/56.

Osmani, L. N. K. (1998) "Impact of Credit on the Relative Well-Being of Women: Evidence from the Grammen Bank" in Sinha, S (ed) Micro credit: Impact, Targeting and sustainability, IDS Bulletin, Vol. 24, No. 9.

Osmani, S. R. (2005). The Employment Nexus between growth and Poverty- An Asian Perspective. Swedish International Development Cooperation Agency, Stokholm, Sweden.

Pingle, V. (2008). "Microenterprise and Sustainable Livelihoods", in Moser, C and Dani, A (eds), Assets, Livelihoods, and Social Policy”, The World Bank, Washington, D.C., pp. 279297.

Republic of Ghana. (1999). "Microfinance - A Strategy for Reducing poverty”, A Paper prepared for the tenth meeting of the consultative group for Ghana, Accra.

Seidu, A. and Bambangi, S. (2006). "Micro-credit and Poverty Alleviation: An analysis of the performance of Women in Micro-credit Activities in Kassena Nankana District of Ghana." Ghana Journal of Development Studies, Vol. 3 (2), pp. 41-56.

Simli Aid. (2005). End of Project Evaluation Report”.

Simli Pong. (2008). "End of Project Evaluation Report".

Sinha, S. (1998). Microcredit: Impact, Targeting and Sustainability. In Sinha, S (ed) Micro credit: Impact, Targeting and sustainability, IDS Bulletin, Vol. 24, No. 9. 
Sinha, S and Matin, I. (1998). "Informal Credit Transactions of Micro-Credit Borrowers in Rural Bangladesh" in Sinha, S (ed) Micro credit: Impact, Targeting and sustainability, IDS Bulletin, Vol. 24, No. 9.

Steel, W. F and Andah, D. O. (2004). "Rural and Microfinance Regulation in Ghana: Implications for Development and Performance of the Industry." A paper presented at the International Conference on Ghana's economy at the half Century, organized by ISSER, University of Ghana and Cornell University, July 18-20, 2004, at M-Plaza Hotel, Accra. Ghana, pp1-48.

Todaro, M.P and Smith, S.C. (2004). Economic Development (8 - Edition), Nutech Photolithographers, India.

United Nations (2005). "Building Inclusive Financial Sectors to Achieve the

Millennium Development Goals.” A Concept Paper. (International Year of Microcredit, United Nations, 2005).

Village Aid, UK. (2006). “Evaluation Report on Re-negotiating corporate policy - CR 1193”.

YOWE. (2005). “End of Project Evaluation Report”. 